\title{
Study on the Application of the Balanced Score Card in Military Financial Management
}

\author{
Kaiyang Xu \\ Logistics University of PAP, Tianjin 300309, China \\ fabulous0134YY0o@163.com
}

\begin{abstract}
At present, the new method of "the Balanced Score Card" has been widely applied in state-owned enterprises and public institutions. With the advancement of Chinese characteristic military reformation and the further development of military transformation, profound changes have taken place in the mission which the army is responsible for. Some new contradictions and problems have appeared in the logistic support area, especially in terms of military financial management, which means that the traditional management area is facing new challenges. Introducing the balanced scorecard method into military financial management will be the inevitable choice for giving full play to the benefit of military expenditure. In this paper, the characteristics of the Balanced Score Card are introduced, the relationship between the indices of the Balanced Score Card and military financial management is analyzed, and the proposition of constructing financial management performance evaluation index content and supporting measures of performance evaluation is put forward.
\end{abstract}

Keywords-Military Finance; The Balanced Score Card (BSC); Management Performance Evaluation

\section{INTRODUCTION}

In the early 1990s, Robert Kaplan and David Norton, the professors from the Harvard Business School, founded "the Balanced Score Card" together, which quickly has been generally recognized and widely disseminated into application after taking the lead in being carried out in 12 well-known enterprises and achieving remarkable results [1]."The Balanced Score Card" is based on the developing strategy of the enterprise, taking the initiative to look for the key factors which can dry success, setting up a complete performance index system, and ensuring the effective implementation of the developing strategy of the enterprise.

The Balanced Score Card is found to be not only adaptable to the management and development of the enterprise, but also suitable to the performance evaluation of military financial management through analyzing and studying [2]. Therefore, the author intends to express some ideas on the introduction of the Balanced Score Card to the performance evaluation of military financial management, combining the military financial management practice.

\section{THE CHARACTERISTICS OF BALANCED SCORE CARD}

The Balanced Score Card is a performance measurement system or performance appraisal index system designed to realize the developing strategy of the enterprise and has the following four characteristics [3]. The first one is the multidimensional nature. The system consists of interrelated multidimensional indices such as finance, internal business process, customer, learning and studying. The second one is the balancing nature. The performance evaluation index of the enterprise is expanded to four dimensions, which means that relationships between financial performance indices and nonfinancial performance indices, between lagging performance indices and front performance indices, and between inside groups and outside groups of the enterprise are well balanced and the comprehensive performance evaluation of the enterprise can be implemented. The third one is the causality. The multidimensional indices of the system have strong causal relationships among each other, for example, the learning and studying index supports the internal business process index, the internal business process index supports the customer index, the customer index supports the finance index, and sustained growth of the finance index provides economic security for the improvement of the learning and studying and the internal business process, which pushes the enterprise step into the track of benign development ring by ring. The forth one is the strategic nature. The establishment of the performance evaluation index system is guided by the long-term development of the enterprise which not only attaches great importance to the measurement of the result index, but emphasizes the evaluation of the long-term developing orientation of the enterprise as well while cultivating the core competitiveness of the enterprise is the key of strategic management. The application of this performance evaluation method not only has changed the traditional practice of using single financial index for performance evaluation, but also can promote the seeking breakthroughs in key areas like products, processes, and customers to achieve strategic objectives consciously [4] 


\section{THE RELATIONSHIP BETWEEN THE INDEX OF THE BALANCED SCORE CARD AND MILITARY FINANCIAL MANAGEMENT}

If we compare the performance evaluation index system of the Balanced Score Card with the elements of military financial management, the following four levels of relevance should be reflected.

\section{A. Finance level}

Income, cost and profit belong to this sort of indices which the enterprise pays the most attention to and is an overall and comprehensive reflection of the final results of business activities and a standard for measuring the value creation capacity of the enterprise. As a consumptive economic activity, military finance doesn't produce economic profits, so the efficiency is very easy to be ignored, leading to the fact that only the compliance with financial laws and regulations is emphasized while the standards measuring the military and economic benefits are neglected during financial management performance evaluation.

\section{B. Internal business process level}

The management condition and business operation situation belong to this sort of indices, which means that the enterprise tries to improve its competitive advantage, produce products that meet the needs of customers and gain maximum profits by taking certain measures and using effective management methods. From the perspective of military financial activities, this sort of indices are also targets measuring financial management and ensure that the financial work operates in an orderly manner and certain military and economic benefits are achieved.

\section{Customer level}

Products situation and after-sales service situation belong to this sort of indices, which means that the enterprise provides cost-effective products, differentiated products and highquality and high-effective after-sales service so as to meet the needs of the customers and gain vitality. For military financial management, "serving the army" should be chosen as the index ensuing that the army operates in an orderly manner and no economic problems appear.

\section{Learning and growth level}

Human resources situation and information technology situation belong to this sort of indices which set leaning and growth indices for the management of people so as to improve operation efficiency, meet the demands of the customers and create value continuously. For military financial management, the learning and growth index is a development target that predicts financial management performance level starting form the potential factor such as learning and growth.

\section{CONSTRUCTION OF THE PERFORMANCE EVALUATION INDEX OF MILITARY FINANCIAL MANAGEMENT BASED ON THE BALANCED SCORE CARD}

By introducing the Balanced Score Card into the designment of the performance evaluation index military financial management, the target can break into four aspectsfinance, business management, serving the army, and leaning and growth, in order to form a performance evaluation index of financial management.

\section{A. Constructive principle of the performance evaluation index of military financial management.}

First, compliance is the basic compliance of financial management activities and the important content of financial management performance evaluation. Efficiency is the ultimate goal of financial management and the foothold of the usage and of management funds. Therefore, the unity of compliance and effectiveness should be pursued in the designment of the performance index, namely, on the basis of the satisfaction of compliance, effectiveness performance index be increased as far as possible to maximize the effective transformation of financial resources to combat security forces and promote the scientific development of the construction of the army.

Second, quantitative index is numerical analysis index which actual value is more intuitive, specific, clear and has reference standards such as funding rate, budget execution rate, balance rate, decision accuracy, family property accumulated rate. Therefore, we should try to refine or quantify the relevant content, make the financial management benefit comparable, improve its operability, ensure the smooth and orderly implementation of the evaluation work in setting the indicators.

Third, we should not only pay attention to the objectivity that set the index number, index name, index points must be scientific, true and clear but also consider the feasibility that data acquisition should be in line with cost-benefit principle in the setting of financial management performance evaluation process.

\section{B. Content of performance evaluation index of military financial management.}

According to the design idea of the Balanced Score Card evaluation index system, the author believes that the following indicators should be set up for the performance evaluation of the military financial management.

\section{1) Finance index}

This indicator is to reflect the results of financial management from the macro perspective, and it is suitable for setting up two indicators: revenue and expenditure and expenditure effect. Revenue and expenditure include maintenance expenditure, constructive expenditure, government expenditure and extra budgetary expenditure cost expenditure ratio. Expenditure effect index includes military benefit, economic benefit, political benefit and social benefit. This index is to reflect the efficiency and effect of the financial management business process from the micro level, suitable for the establishment of standard system implementation, financial decision-making, budget control, reform implementation, 
accounting, fund management, project funds supervision and other seven indicators.

Implementation of standard index system includes the implementation of regulations, publicity, establishing a new system and law enforcement; the financial decision-making indicators includes project basis, overall financial ratio rate, Party collective decision-making accuracy, major issues for collective deliberation rate; the budget control indicators includes funds to invest in investment volume ratio, unit comprehensive budget, department budget, budget breakdown rate, final trial increase (minus) ratio; the implementation of the reform index includes assets into budget ratio, consumption cost of monetary payment reform in direct payments and authorized payment ratio; accounting indicators includes the accounting statement of the qualified rate, the situation of archives management and capital management specification; categories of indicators includes the internal control system implementation, the management of bank accounts and money storage rate, centralized payment ratio, family funds standard rate; the project funds regulatory indicators includes infrastructure investment project supervision, financial supervision, set in procurement of major military operations task special funds supervision and the major asset disposal supervision.

\section{2) Service force index}

This index can reflect whether the financial management activities meet the needs of the army construction and development and whether the welfare of the vast numbers of officers and soldiers timely. It includes four kinds of indicators, such as funds supply, funds allocation, treatment implementation and inspection guidance. The funds supply indicators includes the standard financial accounts receives rate of increase or decrease of project funds, issued settlement rate, reduction rate, to ensure funding for grass-roots trial rate; the funds allocation index includes the maintenance of construction funds and other funds rate; the treatment implementation index includes living expenses supply guarantee the qualified rate, living standards, power control rate of qualified rate, transfer rate and supply qualified officers satisfaction rate; the inspection guidance includes the coverage rate and the problems found rectification rate.

\section{SUPPORTING MEASURES OF INTRODUCING THE BALANCED SCORE CARD INTO THE PERFORMANCE APPRAISAL OF THE MILITARY FINANCIAL MANAGEMENT}

\section{A. Set up a complete organization and implementation procedure}

The performance evaluation of financial management is a complex system engineering, involving all aspects of work, organization so that the coordination is difficult. We must establish and improve a set of scientific and reasonable organization and implementation procedures and form a system to ensure the standardized and orderly evaluation process. Stipulating the division of responsibilities of comprehensive evaluation, refining the method and steps of organization and implementation, clearing the operation rules and revising in time which in order to ensure the participation of appraisal personnel to carry out the evaluation in strict accordance with the operation mode of curing, earnestly fulfill its responsibilities and give full play to its role in promoting financial management performance evaluation work smoothly. Appraisal personnel may rely on the existing system where should set up special positions in the financial sector.

\section{B. Speed up the informatization process of performance appraisal}

"Military finance project" integrates the financial business and lays the foundation for the implementation of financial management performance evaluation. The corresponding evaluation software should be developed as soon as possible according to the standard requirements and embedded in the "military financial engineering" system where business software sets up the index parameters, data extraction and result analysis module. In this way not only can carry out self rating organizations at all levels to create conditions also can simplify the superior business appraisal organization and implementation procedures, greatly shorten the extraction time of various types of data, reduce errors, save manpower investment effectively and enhance the real-time performance evaluation.

Setting up information disclosure module. You can publish financial management performance evaluation results in a certain range, promote the army in accordance with the law management, scientific management, thrifty with money.

\section{Further improve reward and punishment incentive mechanism}

The evaluation without reward and punishment incentive mechanism is an imperfect evaluation. The army should establish and improve the incentive mechanism as an important starting point and strive to achieve the organic combination of responsibility, right and benefit of the three in promoting financial management performance evaluation process. It needs to take strong measures to reward excellence and punish later. Clearly defined performance evaluation failed to reach the standard, the financial department responsible person and the relevant responsible person shall not be rated as advanced. If the two assessment fails to reach the standard, it shall be ordered to be transferred from the financial post. The evaluation of outstanding units and individuals should be given a certain material and spiritual reward to ensure that performance appraisal work plays a positive role in strengthening financial management. 
D. Strive to create a good atmosphere for managing finances according to law

In terms of military financial management, the Balanced Score Card is introduced into the financial management performance evaluation, trying to transform a way to promote the development of financial management work from the formal point of view; it is the design idea of using the Balanced Score Card evaluation index and strive to improve the quality of financial management performance by adjusting the relevant content structure from the formal point of view. Whether it is the conversion of the mode or the adjustment of the content, it is for the financial services according to law. Therefore, we need to vigorously create a good atmosphere of financial management according to law for the introduction of Balanced Score Card to the performance evaluation of the military financial management. The financial staff should strengthen financial regulations and standard system of learning, truly understand the law, law-abiding, law enforcement, perform their duties conscientiously, exercise their power properly in accordance with the law, safeguard the seriousness of the financial regulations and strengthen financial regulations and standard system of publicity and education efforts, enhance the consciousness of the officers and soldiers to participate in the management constantly.

\section{CONCLUSION}

This paper introduces the characteristics of the Balanced Score Card in four aspects. By analyzing the correlation between the Balanced Score Card and the military financial management in four aspects, the Balanced Score Card is introduced into the design of the performance evaluation index of the military financial management. From the financial, business management, service forces, learning and growth in four aspects of decomposition of daily mark, thus forming financial management performance evaluation indicators and performance evaluation supporting measures. There are two advantages in applying Balanced Score Card to military financial management:

(1) The Balanced Score Card can adjust the four performance dimensions of military financial management according to the military mission combined with the actual characteristics of the army. Then, the index in each dimension is decomposed and refined to obtain the data objectively so as to guide the specific action.

(2) From the perspective of performance management, the balanced scorecard can balance the various indicators in the performance evaluation system of the military financial management.

\section{REFERENCES}

[1] Bernhard Smandek, Andreas Barthel, Jens Winkler, Peter Ulbig. Balanced score card implementation for IP rights management in a public research institution [J]. Measuring Business Excellence,2010, p.22.

[2] M. Punniyamoorthy, R. Murali. Balanced score for the balanced scorecard: a benchmarking tool [J]. Benchmarking: An International Journal,2008, p.75.

[3] N Y Wijayanti,W Setiawan, R A Sukamto. Performance Assessment of IT Governance with Balanced Score Card and COBIT 4.1 of Universitas Pendidikan Indonesia [J]. Journal of Physics: Conference Series,2017, p.82.

[4] Christine Fürst,Paul Opdam, Luis Inostroza,Sandra Luque. Evaluating the role of ecosystem services in participatory land use planning: proposing a balanced score card [J]. Landscape Ecology,2014, p.37. 